\title{
Pengaruh Terpaan Berita Suap Pemeriksa di Detik. Com terhadap Sikap Pemeriksa Pada Badan Pemeriksa Keuangan Republik Indonesia Perwakilan Provinsi Sumatera Utara
}

\section{The Influence of News Reporting About Bribery to an Auditor on Detik.Com on The Attitude of The Auditors at The Audit Board of The Republic of Indonesia in North Sumatera Province}

\author{
Fanani Sari Putri \\ Magister Ilmu Komunikasi, Fakultas Ilmu Sosial dan Ilmu Politik, \\ Universitas Sumatera Utara, Indonesia.
}

*Coresponding Email: putrilubis1012@gmail.com

Diterima Februari 2019; Disetujui April 2019; Dipublikasikan April 2019

\begin{abstract}
Abstrak
Tujuan penelitian ini adalah untuk menganalisis pengaruh terpaan pemberitaan tentang kasus suap Pemeriksa BPK RI di Detik.com terhadap sikap pemeriksa BPK RI Perwakilan Provinsi Sumatera Utara, dan untuk menganalis pengaruh faktor individu dan faktor sosial terhadap sikap pemeriksa BPK RI Perwakilan Provinsi Sumatera Utara dalam melaksanakan kode etik pemeriksaan. Penelitian ini menggunakan pendekatan kuantitatif dengan metode korelasional dengan SPSS. Metode pengambilan sampel yang digunakan adalah total sampling, artinya sampel yang digunakan adalah total populasi dengan responden sebanyak 98 orang. Hasil uji hipotesis dalam penelitian ini menunjukkan adanya pengaruh dan hubungan positif yang signifikan. Hasil penelitian menunjukkan bahwa terpaan pemberitaan melalui frekuensi, durasi, kredibilitas, konten dan desain tentang kasus suap Pemeriksa BPK RI memberikan pengaruh terhadap sikap pemeriksa dalam melaksanakan kode etik pemeriksaan dan terdapat faktor individu dan sosial sebagai variabel kontrol menjadi penyebab meningkatnya hubungan dan mempengaruhi sikap pemeriksa.
\end{abstract}

Kata Kunci: Terpaan Berita Suap, Detik.com, Sikap Pemeriksa, BPK RI Sumatera Utara.

\begin{abstract}
The objective of the research was to analyze the influence of news reporting about the case of bribery to the investigator of BPK RI (The Audit Board of the Republic of Indonesia) on Detik.com on the attitude of the auditors at BPK RI in North Sumatera Province, and to analyze the influence of individual as well as social factors on the auditors' attitude in carrying out the ethical code of auditing. It employed quantitative approach with correlational method using SPSS. Total Sampling technique was applied to collect the samples; indicating that the whole population was taken as the samples, namely 98 respondents. The result of the research showed that there was positive impact and significant correlation. The results of the research demonstrated that the news reporting by its frequency, duration, credibility, content and design about the bribery case of an auditor of BPK RI influenced the attitude of the auditors in carrying out auditing procedures and there were individual and social factors as the control variables which increased the correlation and influenced the attitude of the auditor.
\end{abstract}

Keywords: News Reporting on Bribery, Detik.com, Attitude of Auditor, BPK RI Sumatera Utara.

How to Cite: Putri. F.S (2019). Pengaruh Terpaan Berita Suap Pemeriksa di Detik. Com terhadap Sikap Pemeriksa Pada Badan Pemeriksa Keuangan Republik Indonesia Perwakilan Provinsi Sumatera Utara. Jurnal Simbolika. 5 (1): 55-95. 
Fanani Sari Putri, Pengaruh Terpaan Berita Suap Pemeriksa di Detik. Com terhadap

\section{PENDAHULUAN}

Media massa merupakan sumber informasi yang utama dan dinilai kredibel serta tidak dapat dipisahkan dari kehidupan masyarakat. Menurut McQuail (2011), media massa memiliki sifat atau karakteristik yang mampu menjangkau massa dalam jumlah besar dan luas, bersifat publik dan mampu memberikan popularitas kepada siapa saja yang muncul di media massa. Media massa saat ini telah menjadi sumber informasi utama yang dinilai kredibel dan tidak dapat dipisahkan dari kehidupan masyarakat, dalam menjalani aktivitas kesehariannya.

Era millennium baru dan perkembangan teknologi komunikasi, media massa pun telah banyak berubah. Saat ini dunia sudah sangat terhubung menjadi satu, sangat rata sehingga membuat Anda tidak hanya sebatas melihat tempat anda berdiri - seperti melihat sebuah mobil dan seberapa jauh atau tertinggalnya anda. Alasan utamanya adalah kemunculan dan berkembangnya teknologi komunikasi yaitu internet.

Internet memberikan dampak signifikan terhadap perkembangan media massa itu sendiri. Internet merupakan saluran baru dalam berkomunikasi dan berpartisipasi. Internet merupakan media yang mudah dijangkau oleh masyarakat. Internet sebagai media baru (new media), telah menjadi salah satu sumber informasi dalam era kemajuan ilmu pengetahuan dan teknologi termasuk dibidang komunikasi. Berdasarkan data terakhir Internet Worldstats tercatat bahwa Indonesia berada pada urutan ketiga pengakses internet terbanyak di Asia. Data Badan Pusat Statistik tahun 2014, menunjukkan bahwa $78,4 \%$ orang $\mathrm{di}$ Indonesia menggunakan internet untuk mencari berita. Hasil survey APJII tahun 2017 menunjukkan bahwa sebanyak 55,30\% orang Indonesia memanfaatkan layanan informasi melalui internet adalah membaca artikel, dan sebanyak 50,26\% orang Indonesia memanfaatkan internet di bidang sosial-politik untuk membaca berita sosial/lingkungan.

Badan Pemeriksa Keuangan Republik Indonesia (BPK RI) merupakan lembaga negara yang bertugas memeriksa pengelolaan dan tanggungjawab tentang keuangan negara. Dalam mewujudkan tranparansi dan akuntabilitas keuangan negara, BPK RI sebagai lembaga tinggi negara berhak untuk melakukan pemeriksaan atas Laporan Keuangan Pemerintah baik pemerintah pusat maupun pemerintah daerah. Hasil pemeriksaan atas pengelolaan keuangan tersebut, BPK RI berwenang untuk menyatakan opini atas laporan keuangan negara/daerah yang diserahkan oleh 
pemerintah pusat/daerah tersebut. Opini Wajar Tanpa Pengecualian (WTP) merupakan predikat terbaik yang diberikan terhadap Laporan Keuangan.

Liputan media dan pemberitaan atas keberhasilan memperoleh opini WTP sepertinya menjadi trend di berbagai daerah. Euphoria tersebut menimbulkan kekhawatiran bahwa pemerintah memperoleh opini WTP dari BPK bukan karena informasi yang disajikan dalam laporan keuangan dinilai bebas dari salah saji material melainkan karena adanya faktor lain.

Pendapat tentang adanya faktor lain di luar substansi keuangan negara dalam memperoleh opini WTP banyak dikaitkan dengan jual beli opini. Divisi Riset Indonesian Corruption Watch (ICW) mengatakan pihaknya sudah mendata kasus penyimpangan terkait auditor BPK. "Kita lihat misalnya apa yg terjadi pada auditor ini bukan pertama kali. Mungkin sejak 2004 sudah ada delapan kasus yang melibatkan auditor atau pejabat BPK. Terkait itu dalam jual-beli opini atau terkait dalam proses pemeriksaan" kata Firdaus dari Divisi Riset ICW (Detik.com 6 Juni 2017).

Selain melaksanakan fungsi menyediakan informasi, pemberitaan kasus tindak pidana korupsi oleh media juga merupakan perwujudan pelaksanaan fungsi pengawasan. Pemberitaan kasus tindak pidana korupsi dapat menjadi pegawasan peringatan/warning surveillance (Laswell, dalam Nurudin, 2013) bagi para penyelenggara negara agar dalam melaksanakan pengelolaan dan pengawasan keuangan negara/daerah taat azas dan mematuhi peraturan yang berlaku.

Pemberitaan tentang BPK yang menarik perhatian dan menjadi topik berita termasuk pada portal online adalah kasus suap dalam operasi tangkap tangan (OTT) oleh Komisi Pemberantasan Korupsi (KPK). Berdasarkan jumlah pemberitaan kasus suap melalui portal berita online dapat diuraikan bahwa portal berita online "detik.com" merupakan media yang paling banyak memberitakan kasus suap dan paling banyak dibaca beritanya, yaitu sebanyak 190 berita.

Banyaknya pemberitaan kasus suap auditor melalui situs berita online tentunya dapat menimbulkan pengaruh terhadap pemeriksa BPK. Terpaan media melalui situs berita online akan mempengaruhi perubahan sikap seseorang. Jadi, apabila seseorang terus menerus diterpa oleh informasi media yang dipercayainya, hal pertama yang terjadi adalah bertambahnya pengetahuan dan selanjutnya ada kemungkinan terjadi perubahan perilaku (Effendy, 2006) Efek 
Fanani Sari Putri, Pengaruh Terpaan Berita Suap Pemeriksa di Detik. Com terhadap

yang ditimbulkan dapat berupa efek kognitif, efek afektif, dan efek behavioral. Tentunya pengaruh pemberitaan terhadap perubahan sikap pemeriksa dalam mengonsumsi media dapat ditinjau dari seberapa sering mereka terterpa isi media serta tingkat pengetahuan dan pemahaman yang dimiliki oleh masingmasing individu.

Pemberitaan-pemberitaan kasus suap pemeriksa melalui operasi tangkap tangan (OTT) KPK pada situs berita Detik.com menjadi alasan peneliti untuk melakukan kajian tentang adanya pengaruh pemberitaan terhadap khalayak dhi. pemeriksa BPK Perwakilan Provinsi Sumatera Utara. Selain alasan tersebut, dipilihnya portal berita online Detik.com karena detik.com merupakan portal berita dan artikel daring salah satu situs berita terpopuler di Indonesia. Portal ini dinilai banyak kalangan sebagai portal terdepan dalam hal berita-berita baru (breaking news).

Berdasarkan latarbelakang dan rumusan masalah yang telah diuraikan diatas, maka tujuan penelitian ini adalah untuk: 1) Untuk menganalisis pengaruh terpaan pemberitaan tentang kasus suap Pemeriksa BPK RI di Detik.com terhadap sikap pemeriksa BPK RI Perwakilan Provinsi Sumatera Utara dalam melaksanakan kode etik pemeriksaan. 2)
Untuk menganalis pengaruh faktor individu terhadap sikap pemeriksa BPK RI Perwakilan Provinsi Sumatera Utara dalam melaksanakan kode etik pemeriksaan. 3) Untuk menganalisis pengaruh faktor sosial pada hubungan antara terpaan tentang pemberitaan kasus suap pemeriksa BPK di Detik.com terhadap sikap pemeriksa.

Berdasarkan latar belakang dan rumusan masalah dapat dirumuskan hipotesis sebagai berikut:

H2 :Terdapat pengaruh tentang pemberitaan terpaan tentang pemberitaan kasus suap pemeriksa BPK di Detik.com terhadap sikap pemeriksa.

H2 : Terdapat pengaruh faktor individu pada hubungan antara terpaan tentang pemberitaan kasus suap pemeriksa BPK di Detik.com terhadap sikap pemeriksa.

H3 : Terdapat pengaruh faktor sosial pada hubungan antara terpaan tentang pemberitaan kasus suap pemeriksa BPK di Detik.com terhadap sikap pemeriksa.

\section{METODE PENELITIAN}

Penelitian ini merupakan penelitian metodologi kuantitatif, menggunakan pendekatan kuantitatif dengan metode korelasional. Tipe ini menghubungkan dua atau lebih konsep variabel yang akan diteliti (Kriyantono, 2010). 
Adapun lokasi penelitian berada di Badan Pemeriksa Keuangan (BPK) Perwakilan Provinsi Sumatera Utara.

Menurut Kelinger (dalam Kriyantono, 2010) menyebut konsep sebagai abstraksi yang dibentuk mengeneralisirkan hal-hal khusus. Definisi konsepsional adalah batasan-batasan tentang pengertian yang diberikan oleh peneliti terhadap variabelvariabel yang hendak diukur, diteliti dan digali datanya.

Operasional variabel dalam penelitian ini adalah sebagai berikut: 1) Variabel Bebas (X) dalam penelitian ini adalah terpaan berita kasus suap pemeriksa di Detik.com; 2) Variabel Terikat (Y) dalam penelitian ini adalah Sikap Pemeriksa; 3) Variabel Terikat (Z) dalam penelitian ini adalah Faktor sosial dan individu. Karakteristik Responden pada penelitian ini adalah nama, jenis kelamin, usia, tingkat pendidikan, pangkat/golongan, jabatan pemeriksa, pengalaman kerja.

Tabel 1. Variabel Operasional

Variabel Teoritis Variabel Operasional

Terpaan Berita Suap Frekuensi

Pemeriksa di Durasi

Detik.com (X) Kredibelitas

(Ardiyanto dan Konten

Erdinaya, 2005, Desain

Romli, 2018)

Sikap (Y) Kognitif

(Azwar, 2005) Afektif

$\begin{array}{lll} & \text { Konatif/Behavioral } \\ \text { Variabel Kontrol (Z) } & \text { Faktor Sosial dan }\end{array}$

individu
Sumber: Hasil penelitian Tahun 2018
Metode pengambilan sampel yang digunakan adalah total sampling, artinya sampel yang digunakan adalah total populasi. Metode ini diperbolehkan kerena jumlah populasi dalam penelitian ini yang terbatas atau sedikit, yaitu 98 responden, sehingga dari jumlah tersebut dijadikan sampel dalam penelitian. Menurut Arikunto (2006) Jika subjek kurang dari 100, lebih baik diambil semua sehingga penelitiannya merupakan penelitian populasi.

Skala pengukuran variabel yang digunakan dalam penelitian ini merupakan skala Likert. Menurut Sugiyono (2014) Skala Likert digunakan untuk mengukur sikap, pendapat, dan persepsi seseorang atau sekelompok orang terhadap fenomena sosial.

Data primer diperoleh dari jawaban responden terhadap kuesioner yang disebarkan kepada sampel yaitu pegawai Badan Pemeriksa Keuangan Ri Perwakilan Sumatera Utara, kuesioner ini dimaksudkan untuk mendapatkan data yang dibutuhkan untuk memperoleh informasi dari responden mengenai terpaan pemberitaan tentang kasus suap Pemeriksa BPK RI di Detik.com terhadap sikap pemeriksa BPK RI Perwakilan Provinsi Sumatera Utara. Data sekunder adalah data yang diperoleh dalam bentuk yang sudah diolah berupa dokumen 
Fanani Sari Putri, Pengaruh Terpaan Berita Suap Pemeriksa di Detik. Com terhadap

organisasi dan publikasi yang melaksanakan kode etik pemeriksaan dikumpulkan oleh pihak atau instansi lain. (variabel Y). Hal ini dapat dilihat pada Data sekunder dalam penelitian ini meliputi profil BPK RI Perwakilan Provinsi Sumatera Utara, struktur organisasi dan data yang diperoleh dari hasil pengolahan buku, teori-teori dan literatur yang berhubungan dengan masalah yang diteliti. Pengolahan data dilakukan dengan bantuan aplikasi komputer SPSS. Telah dilakukan juga uji validitas dan reliabilitas instrumen penelitian.

Uji hipotesis dilakukan dengan menggunakan uji korelasi Spearman Rank. Teknik ini digunakan untuk mengetahui koefisien korelasi atau derajat kekuatan hubungan. Teknik ini digunakan tanpa melihat apakah suatu variabel tertentu tergantung kepada variabel lainnya. (Kriyantono, 2010).

\section{HASIL DAN PEMBAHASAN}

Pengaruh Terpaan Pemberitaan Tentang Kasus Suap Pemeriksa BPK RI Di Detik.Com Terhadap Sikap Pemeriksa BPK RI Perwakilan Provinsi Sumatera Utara.

Terpaan pemberitaan dalam

penelitian ini, terdiri dari lima variabel antara lain: frekuensi dan durasi, kredibilitas media, konten dan desain. Berdasarkan uji korelasi diketahui bahwa ke lima variabel tersebut berpengaruh terhadap sikap pemeriksa BPK RI Perwakilan Provinsi Sumatera Utara dalam tabel berikut:

Tabel 2. Hasil Uji Korelasi Spearman Rank Correlations

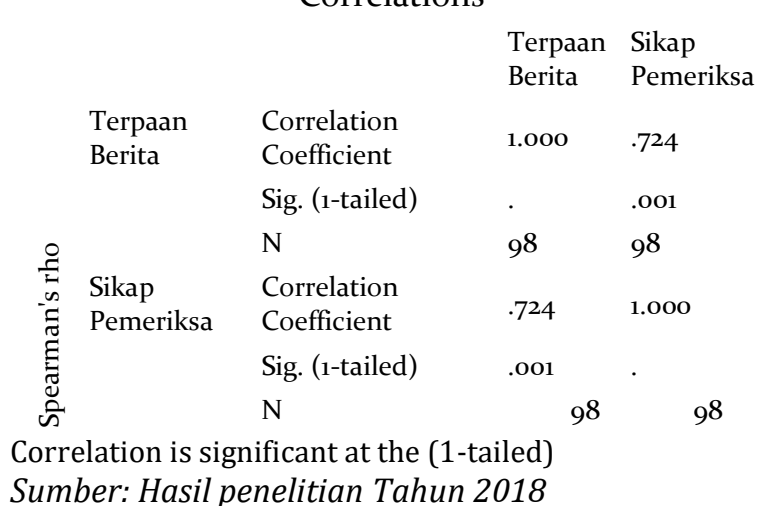

Sumber: Hasil penelitian Tahun 2018

Hal ini diketahui pada tabel 2 diketahui nilai koefisien korelasi adalah 0.724 artinya terdapat hubungan yang sangat signifikan antara terpaan pemberitaan tentang kasus suap Pemeriksa BPK RI di Detik.com dan sikap pemeriksa BPK RI Perwakilan Provinsi Sumatera Utara dalam melaksanakan kode etik pemeriksaan. Dari penelitian juga diketahui nilai signifikansi adalah 0.001 artinya terpaan pemberitaan tentang kasus suap Pemeriksa BPK RI di Detik.com berpengaruh terhadap sikap pemeriksa BPK RI Perwakilan Provinsi Sumatera Utara dalam melaksanakan kode etik pemeriksaan.

Terpaan media juga dapat didefinisikan sebagai penggunaan media baik penggunaan jenis media, frekuensi maupun durasi penggunaan (longevity) (Zillmann, 2004). Kemudian Flander (Flander, 2009) menjelaskan bahwa 
terpaan media adalah banyaknya informasi yang diperoleh melalui media, yang meliputi frekuensi, atensi dan durasi penggunaan pada setiap jenis media yang digunakan.

Media online dalam menyebarkan informasi dituntut untuk memperhatikan aspek penting dalam pemberitaan, yakni kredibilitas. Berita yang disampaikan oleh media online tidak bisa lepas dari aspek kredibilitas yang harus selalu dipertahankan. Variabel lain dalam terpaan yang dianalisis adalah kredibilitas media, konten dan desain pada website berita online.

Salah satu fungsi dari media massa adalah fungsi pengawasan (Nurudin, 2013). Informasi mengenai berbagai kasus suap pemeriksa BPK yang diterima oleh responden menjadi sumber pengetahuan antara lain mengenai kasus yang sedang terjadi, pelaku yang terlibat, modus yang digunakan, nilai kerugian yang timbul, dan lain sebagainya. Informasi-informasi tersebut menjadi sebuah pengetahuan atau wawasan bagi responden yang merupakan bagian dari unsur kognitif yang dimiliki responden.

Terpaan pemberitaan kasus suap pemeriksa di website berita online mendorong timbulnya upaya dan komitmen dari pemeriksa dalam melaksanakan kode etik, yakni meningkatkan keahlian/kompetensi, bekerja secara jujur, dan independen agar dapat terhindar dari tindak pidana korupsi. Sikap yang dimiliki oleh pemeriksa, menurut Rakhmat (2015) terdiri dari unsur kognitif yakni pengetahuan dan pemahaman akan berbagai hal yang berkaitan dengan kasus suap seperti: kasus yang terjadi, siapa yang terlibat dan nilai kerugian negara/daerah yang timbul. Unsur afektif berupa perasaan optimis dalam menjalankan tugas baik sebagai pemeriksa. Terakhir, unsur konatif yaitu timbulnya komitmen untuk meningkatkan keahlian dan kompetensi serta komitmen untuk bekerja secara jujur.

Sebagaimana dijelaskan sebelumnya, sikap seseorang terbentuk karena adanya interaksi dengan orang lain serta adanya stimuli atau objek luar yang mempengaruhi (Azwar, 2005). Terdapat faktor-faktor yang turut mempengaruhi pola perilaku individu. Faktor-faktor tersebut kemudian turut mempengaruhi pembentukan sikap yakni pengalaman pribadi, kebudayaan, orang lain yang dianggap penting, media massa, institusi atau lembaga pendidikan, lembaga agama, serta faktor emosi dalam diri individu.

Sikap pemeriksa pada BPK Perwakilan Provinsi Sumatera Utara tidak hanya terbentuk dari adanya 
Fanani Sari Putri, Pengaruh Terpaan Berita Suap Pemeriksa di Detik. Com terhadap

informasi/berita yang disampaikan melalui media online. Lembaga pendidikan pun memiliki peran yang penting dalam pembentukan sikap pemeriksa. Hal ini dikarenakan, lembaga pendidikan memiliki peran untuk meletakkan dasar pengertian dan konsep moral dalam diri setiap pemeriksa. Pemahaman kode etik pemeriksa sebagai konsep moral yang dibentuk oleh Badan Pemeriksa Keuangan tentunya memerlukan peran lembaga pendidikan. Pemahaman baik dan buruk, garis pemisah antara sesuatu yang boleh dan tidak boleh akan diperoleh dari lembaga pendidikan.

\section{Faktor Individu Mempengaruhi Sikap Pemeriksa BPK RI}

Dari hasil uji korelasi diketahui bahwa pengaruh faktor individu sebagai variabel kontrol (Z) terhadap terpaan berita kasus suap pemeriksa BPK RI Perwakilan Hal ini diketahui pada tabel 3 diketahui nilai koefisien korelasi adalah 0.739 artinya keeratan hubungannya masih kuat dan nilai signifikansi menjadi 0.000 dari sebelumnya 0.001 artinya signifikansinya sangat signifikan. Hal ini berarti terdapat hubungan yang kuat dan faktor individu mempengaruhi terpaan berita kasus suap pemeriksa BPK RI di Detik.com terhadap sikap pemeriksa BPK RI Perwakilan Provinsi Sumatera Utara (Y) dalam melaksanakan kode etik pemeriksaan.
Provinsi Sumatera Utara (Y) dapat digambarkan sebagai berikut:

Tabel 3. Hasil Uji Korelasi Partial Faktor Individu Correlations

\begin{tabular}{|c|c|c|c|c|c|}
\hline \multicolumn{3}{|c|}{ Control Variables } & $\begin{array}{l}\text { Terpaan } \\
\text { Berita }\end{array}$ & $\begin{array}{l}\text { Sikap } \\
\text { Pemer } \\
\text { iksa }\end{array}$ & $\begin{array}{l}\text { Jenis } \\
\text { kelamin }\end{array}$ \\
\hline \multirow{3}{*}{\multicolumn{2}{|c|}{$\begin{array}{l}\text { Terpaan } \\
\text { Berita }\end{array}$}} & Correlation & 1.000 & .724 & .592 \\
\hline & & $\begin{array}{l}\text { Significanc } \\
\text { e (1-tailed) }\end{array}$ & . & .001 & .031 \\
\hline & & Df & o & 96 & 96 \\
\hline & Sikap & Correlation & .724 & 1.000 & .653 \\
\hline & Pemeriksa & $\begin{array}{l}\text { Significanc } \\
\text { e (1-tailed) }\end{array}$ & .001 & $\cdot$ & .009 \\
\hline & & Df & 96 & o & 96 \\
\hline \multirow{5}{*}{ 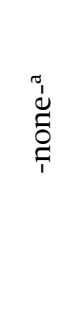 } & Jenis & Correlation & .592 & .653 & 1.000 \\
\hline & kelamin & $\begin{array}{l}\text { Significanc } \\
\text { e (1-tailed) }\end{array}$ & .031 & .009 & · \\
\hline & & Df & 96 & 96 & $\mathrm{O}$ \\
\hline & Terpaan & Correlation & 1.000 & .739 & \\
\hline & Berita & $\begin{array}{l}\text { Significanc } \\
\text { e (1-tailed) }\end{array}$ & $\cdot$ & .000 & \\
\hline \multirow{4}{*}{ 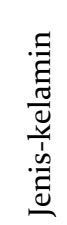 } & \multirow{4}{*}{$\begin{array}{l}\text { Sikap- } \\
\text { Pemeriksa }\end{array}$} & Df & $\mathrm{O}$ & 95 & \\
\hline & & Correlation & .739 & 1.000 & \\
\hline & & $\begin{array}{l}\text { Significanc } \\
\text { e (1-tailed) }\end{array}$ & .000 & $\cdot$ & \\
\hline & & Df & 95 & $\mathrm{O}$ & \\
\hline
\end{tabular}

Cells contain zero-order correlations.

Sumber: Hasil penelitian Tahun 2018

Hal ini membuktikan bahwa variabel kontrol faktor individu (jenis kelamin) penting dalam melihat hubungan antara terpaan berita kasus suap pemeriksa BPK RI di Detik.com terhadap sikap pemeriksa BPK RI Perwakilan Provinsi Sumatera Utara (Y) dalam melaksanakan kode etik pemeriksaan.

Faktor jenis kelamin menjadi faktor yang menentukan lingkungan sosial lembaga seseorang. (Nurudin, 2007). Individu akan ikut bergabung pada kelompok mana dan yang sesuai dengan usia serta jenis kelaminnya. 
Faktor individu (jenis kelamin) secara spesifik memberikan celah pemikiran untuk menguraikan hal-hal apa saja yang mempengaruhi terbentuknya efek. Terlebih dalam pengonsumsian informasi, seseorang dipengaruhi oleh faktor psikologis dalam dirinya serta lingkungan sosial untuk menentukan media apa yang menjadi sumber informasinya.

\section{Faktor Tingkat Pendidikan Mempengaruhi Sikap pemeriksa BPK RI}

Hal ini diketahui pada table 4 diketahui nilai koefisien korelasi adalah sebesar 0.724 , dan taraf signifikansi $\mathrm{p}=$ $0.000(<0.05)$ yakni 0.001 , serta jumlah responden adalah 98 orang dan kita menggunakan N-2 yaitu 98-2 = 96. Hal ini menunjukkan keeratan hubungan yang sangat kuat dan terdapat pengaruh antara terpaan berita kasus suap pemeriksa BPK RI di Detik.com terhadap sikap pemeriksa BPK RI Perwakilan Provinsi Sumatera Utara (Y) dalam melaksanakan kode etik pemeriksaan.

Dari hasil uji korelasi diketahui bahwa pengaruh faktor sosial sebagai variabel kontrol (Z) terhadap terpaan berita kasus suap pemeriksa BPK RI Perwakilan Provinsi Sumatera Utara (Y) dapat digambarkan sebagai berikut:
Tabel 4. Hasil Uji Korelasi Partial Faktor Sosial Correlations

\begin{tabular}{|c|c|c|c|c|}
\hline \multicolumn{2}{|c|}{ Control Variables } & $\begin{array}{l}\text { Terpaan } \\
\text { Berita }\end{array}$ & $\begin{array}{l}\text { Sikap } \\
\text { Pemeriks } \\
\text { a }\end{array}$ & $\begin{array}{l}\text { Tingkat } \\
\text { Pendidika } \\
\mathrm{n}\end{array}$ \\
\hline \multirow{3}{*}{$\begin{array}{l}\text { Terpaan } \\
\text { Berita }\end{array}$} & Correlation & 1.000 & .724 & 589. \\
\hline & $\begin{array}{l}\text { Significanc } \\
\text { e (1-tailed) }\end{array}$ & . & .001 & .072 \\
\hline & Df & o & 96 & 96 \\
\hline \multirow{3}{*}{$\begin{array}{l}\text { Sikap } \\
\text { Pemeriks } \\
\text { a }\end{array}$} & Correlation & .724 & 1.000 & .610 \\
\hline & $\begin{array}{l}\text { Significanc } \\
\text { e (1-tailed) }\end{array}$ & .001 & . & .002 \\
\hline & Df & 96 & o & 96 \\
\hline \multirow{4}{*}{ 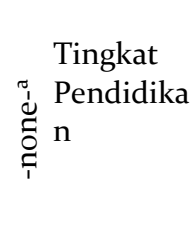 } & Correlation & 589 & .610 & 1.000 \\
\hline & $\begin{array}{l}\text { Significanc } \\
\text { e (1-tailed) }\end{array}$ & .072 & .002 & . \\
\hline & Df & 96 & 96 & o \\
\hline & Correlation & 1.000 & .751 & \\
\hline \multirow{5}{*}{ 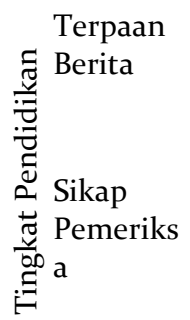 } & $\begin{array}{l}\text { Significanc } \\
\text { e (1-tailed) }\end{array}$ & . & .001 & \\
\hline & Df & o & 95 & \\
\hline & Correlation & .751 & 1.000 & \\
\hline & $\begin{array}{l}\text { Significanc } \\
\text { e (1-tailed) }\end{array}$ & .001 & . & \\
\hline & Df & 95 & o & \\
\hline
\end{tabular}

Setelah digunakan variabel kontrol faktor sosial (tingkat pendidikan) jumlah sampel diketahui $\mathrm{df}=\mathrm{N}-\mathrm{k}-1$ artinya $\mathrm{N}=$ jumlah responden, $\mathrm{k}=$ jumlah variabel, maka 98-2-1 =95 responden, maka diketahui nilai koefisien korelasi menjadi lebih tinggi yakni 0.751 dari 0.724 artinya keeratan hubungan kuat dan nilai signifikansi menjadi 0.000 dari sebelumnya 0.000 yang berarti sangat signifikan. Hal ini menunjukkan terdapat hubungan yang kuat pada faktor sosial yakni tingkat pendidikan, mempengaruhi terpaan berita kasus suap pemeriksa BPK RI di Detik.com terhadap sikap pemeriksa BPK RI Perwakilan Provinsi Sumatera 
Fanani Sari Putri, Pengaruh Terpaan Berita Suap Pemeriksa di Detik. Com terhadap

Utara (Y) dalam melaksanakan kode etik pemeriksaan.

Faktor tingkat pendidikan yang berbeda akan menentukan proses penerimaan pesan. Tingkat pendidikan akan mempengaruhi minat seseorang terhadap ketertarikannya dengan sebuah berita (Nurudin, 2007).

Hal ini menunjukkan bahwa variabel, faktor individu (jenis kelamin) dan faktor sosial (tingkat pendidikan) merupakan bagian penting dijadikan sebagai variabel kontrol karena merupakan penyebab meningkatnya pengaruh terpaan berita kasus suap pemeriksa BPK RI di Detik.com terhadap sikap pemeriksa BPK RI Perwakilan Provinsi Sumatera Utara dalam melaksanakan kode etik pemeriksaan.

Sesuai hasil penelitian diketahui kedua variabel kontrol yakni faktor individu dan faktor sosial tersebut mempunyai hubungan positif yang signifikan dan mempengaruhi terpaan berita kasus suap pemeriksa BPK RI di Detik.com terhadap sikap pemeriksa BPK RI Perwakilan Provinsi Sumatera Utara (Y) dalam melaksanakan kode etik pemeriksaan.

\section{SIMPULAN}

Terpaan berita online melalui website yang terdiri dari item frekuensi dan durasi, kredibilitas, konten dan desain.
Secara umum keseluruhan item menunjukkan hasil penilaian yang cukup baik, terutama frekuensi dan durasi. Hal ini menggambarkan bahwa frekuensi dan durasi responden dalam mengakses dan membaca berita suap Pemeriksa di website berita online sangat signifikan. Artinya terdapat hubungan positif yang sangat signifikan antara terpaan pemberitaan tentang kasus suap Pemeriksa BPK RI di Detik.com dan sikap pemeriksa BPK RI Perwakilan Provinsi Sumatera Utara dalam melaksanakan kode etik pemeriksaan.

Pada faktor individu yakni jenis kelamin, hasil penelitian menunjukkan pengaruh yang sangat signifikan artinya terdapat faktor individu (jenis kelamin) memberikan hubungan yang kuat dan pengaruh antara terpaan berita kasus suap pemeriksa BPK RI di Detik.com terhadap sikap pemeriksa BPK RI Perwakilan Provinsi Sumatera Utara dalam melaksanakan kode etik pemeriksaan.

Selain faktor individu, faktor sosial yakni tingkat pendidikan memiliki pengaruh yang signifikan. Hal ini menunjukkan bahwa faktor sosial yakni tingkat pendidikan memberikan pengaruh dan hubungan yang kuat antara terpaan berita kasus suap pemeriksa BPK RI di Detik.com terhadap sikap pemeriksa BPK RI Perwakilan Provinsi Sumatera Utara (Y) 
dalam melaksankan kode etik pemeriksaan.

\section{DAFTAR PUSTAKA}

APJII. (2017). Penetrasi dan Perilaku Pengguna Internet di Indonesia Tahun 2017. Infografis Hasil Survey.

Arikunto, S. (2006). Prosedur Penelitian Suatu Pendekatan Praktik. Jakarta : Rineka Cipta

Azwar, S. (2005). Sikap Manusia Teori dan Pengukurannya. Yogyakarta: Pustaka Belajar

Ardiyanto, E, Edinaya, L.K. \& Erdiyana. (2005). Komunikasi Massa. Bandung: Remaja Rosdakarya

Effendy, O.U. (2006). Ilmu Komunikasi, Teori dan Praktek. Bandung: PT Remaja.

Flander, G.B. (2009) Exposure of Children to Sexual Content on the Internet in Croatia. Journal, Child Abuse \& Neglect 33, 849-856.
Kriyantono, R. (2010). Teknik Praktis Riset Komunikasi: Disertai Contoh Praktis Riset Media, Public Relations, Advertising, Komunikasi Organisasi, Komunikasi Pemasaran. Jakarta: Kencana.

McQuail, D. (2011). Teori Komunikasi Massa McQuail. Edisi 6. Buku 1. Jakarta: Salemba Humanika.

Nurudin. (2013). Pengantar Komunikasi Massa. Jakarta: PT. Rajagrafindo Persada.

Romli, A.S.M. (2018) Jurnalistik Online. Bandung: Nuansa Cendekia.

Rakhmat, J. (2015). Psikologi Komunikasi. Bandung: PT Remaja Rosdakarya.

Sugiyono. (2014). Metode Penelitian Kuantitatif, Kualitatif dan R\&D. Bandung: Penerbit Alfabeta.

Zillmann, et al. (2004) Effects of Lead Framing on Selective Exposure to Internet News Reports. Journal, Communication Research, Vol. 31 No. 1, February 2004 58-81. DOI: $10.1177 / 0093650203260201$. 